\title{
Book review: Biodiversités en partage. Reconfigurations de ruralités dans le corridor forestier betsileo tanàla (Madagascar)
}

\author{
Christian Kull \\ Institut de géographie et durabilité, Université de Lausanne, Lausanne, Switzerland \\ Correspondence to: Christian Kull (christian.kull@unil.ch)
}

Published: 9 December 2016

Rakoto Ramiarantsoa, H. and Blanc-Pamard, C.: Biodiversités en partage. Reconfigurations de ruralités dans le corridor forestier betsileo tanàla (Madagascar), À travers champs, IRD Éditions, Marseille, 263 pp., ISBN-13: 978-27099-1832-9, EUR 42.00, 2014.

The second thesis of political ecology, according to Paul Robbins (2012), is that conservation policies lead to damaging restrictions on rural livelihoods and thus failure. But in most places, the story is not quite black and white. Protected areas and other conservation strategies are implemented by a variety of people, representing different institutions - whether local, national, or foreign - with diverse goals, means, and constraints, in unique socio-ecological landscapes. Park projects are negotiated in local societies and local landscapes, with different outcomes for different people. This excellent, richly empirical book shows what this nitty-gritty jumble of processes looks like from the perspective of rural residents. In more theoretical terms, the book asks how environmental projects (projets d'écologisation) in rural spaces interfere with forms of social and territorial organization. Do these projects fundamentally re-organize local social and territorial organization, or simply cause adjustments?

Biodiversités en partage is a detailed investigation of the social, agrarian, institutional, and landscape transformations in Madagascar's highly prized, highly diverse rainforests. It is significant for three reasons. First, the book gives a different reading of local conservation politics than usual (in Madagascar and elsewhere). Instead of beginning from conservation projects and policies, or from outsider critiques, it assumes a rural farmer perspective, following their own logic and terminology. As such it emphasizes two aspects not so common in the critical conservation literature: detailed kinship and spatial-territorial analysis.

Second, the book is an important example of the convergence of the Anglo-American tradition of political ecology (and its concerns with struggles over resource control) with French geographical traditions (Gautier and Hautdidier, 2015), including tropical geography and its extremely rich empirical, and agronomic, focus, as well as the tradition of regional planning and development and its central concept of territoire. Both authors have built bridges with political ecology: Blanc-Pamard through a long-standing collaboration with Tom Bassett (e.g., Bassett et al., 2007) and Rakoto Ramiarantsoa through a breakthrough political ecology summer school held in Montpellier in 2009. The result is a rich, careful empirical piece quite attentive to the "politics" of winners and losers.

Third, this work marks the final output of a long-time, productive research partnership between geographers Hervé Rakoto Ramiarantsoa of Madagascar and Chantal BlancPamard of France. Rakoto's untimely death in 2015 sadly occurred not long after he took up a professorship at the University of Bordeaux; Blanc-Pamard, a research director with the CNRS, retired from her position at EHESS, Paris, in 2013. With over a dozen joint publications to their names (including the earlier books Le terroir et son double and Géopolitique et environnement), they painted a robust, empathetic picture of the lives and landscapes of the peasants of highland Madagascar (Blanc-Pamard and Rakoto Ramiarantsoa, 1993a, b, 2000, 2003, 2004, 2007; Rakoto Ramiarantsoa et al., 2012).

The title of the present work, Biodiversités en partage, was, as always, carefully selected, playing on the dual mean- 
ings of partager as both sharing and dividing. In their interpretation of Paul Robbins' metaphor of the hatchet and the seed, the predominant hypothesis of environmental policies and projects in Madagascar is that sharing-dividing the forest between different groups of actors is a "seed" for linking environmental management with local and regional development and, thus, contributing to the fight against poverty. They propose, in the book, to evaluate this and two alternate readings. The first alternative is that environmental initiatives are more of a "hatchet", destabilizing the agrarian systems of the rainforest villagers. The second is that the initiatives are both hatchet and seed, changing people's resource access and power relations in this territory with unequal effects.

The book investigates four villages along a rough transect through Madagascar's eastern rainforest, roughly following the small-gauge Fianarantsoa to Manakara train line. This is the liminal zone between highland Betsileo people and the Tanala, people of the forest. The villages are also at the margins of Ranomafana National Park, established in 1991, and smack in the middle of le Corridor, the Ambositra Vondrozo forest corridor (COFAV), a new protected area decreed in 2006 in the rush to triple the country's conservation areas. As a result, various conservation-, development-, and community-based natural resource management projects have been implemented across the region.

The "Introduction" sets the stage by reminding the reader just how much conservation politics have changed the social, political, and economic terrain in Madagascar. Firstly, it shows how the periphery has become the core: distant village lands and forests at the margins of their territories are now the center of state policy making due to the new emphasis on biodiversity and carbon. Secondly, for the same reasons, public policy, or regional development planning, now has an environmental dimension. It has been "ecologized" - which leads to the research question of how biodiversity is inserted into territoire, i.e., into regional planning, policy, and governance for sustainable development. More specifically, the authors ask how these "ecologized" actions and governance tools change the lives and livelihoods of rural communities in the corridor.

Part 1 of the book includes three chapters. The first introduces the western margin of the forest, at the edge of the historical Lalangina kingdom; the second shifts to the eastern forest front, a historical meeting point of Betsileo and Tanala ethnic groups. In classic monographic style, we read of the history, the topography, the soils, the climate, the hydrography, the local livelihood and agronomic system on each side of the forest. Rakoto Ramiarantsoa and Blanc-Pamard also explain the local social hierarchies, paying particular attention to kinship and lineage groups and how these relate to people's land rights and settlement patterns. As in much of their work, they pay careful attention to local terms - for types of forests, for agrarian techniques, or for toponymy demonstrating how naming also plays a role in the work of dividing space and power.
The third chapter then reviews the reasons for global interest in Madagascar's forest biodiversity and follows with a quick history of the island's conservation and environmental policy. The highlight here is an explanation of how successive policies and interventions divide the land into diverse, overlapping, confusing zones and territories. There are lineage-based customary land rights; administrative divisions into village territories (fokontany) and rural municipalities (communes rurales); the national park (with its core conservation area and buffer zones); the national forest domain and its diverse management zones, including licensed farming areas (périmètres de culture); and contractual CBNRM forest management territories with a bewildering array of usage zones - ZOC, ZUC, ZS, ZUD, TDC - ranging from protected forest to controlled use, and now to be overlain by the new COFAV protected area.

Part 2 investigates what happens when conservation measures run up against rural livelihoods in this messy territorial matrix. Chapter 4 delves into the history of conservation in Madagascar again, noting how policies over the decades have slipped from nature protection, to biodiversity management, to payments for ecosystem services. The authors' point of interest is how these new ideas, representing global trends, then get translated (both literally and figuratively) into local terminology, structures, and management tools like maps. These translations involve collaboration between conservation agencies and regional representatives of the government's ministries (like foresters and land registries), and local communities (but the latter is more in principle than in reality). To illustrate such translations, the authors deconstruct in detail the process of building a zoning map for community-based forest management in the village of Ambendrana, highlighting, for instance, the preponderant role of the GIS technician. They also highlight how the translation of certain words (conservation, renewable natural resources, village territory) leads to confusion in their implementation at the village level.

Chapter 5 highlights how "life territories" have been affected by conservation policies. It begins with three detailed case studies highlighting the uncertainties and negotiations surrounding farmers' expansion of their cultivable lands into the forest, and how they seek to defend their land rights against conservation enclosures. They show how traditional agrarian dynamics in the forest are increasingly shaped by conflict and fears of expulsion. The next set of cases investigates how locals circumvent increased restrictions on important forest-based livelihood activities, including the fabrication of spade handles, crayfish harvesting, and slash-andburn cultivation. In a telling story, they narrate how farmers engineered a putsch in one village's community forest management association ("COBA"), getting the initial president (a school teacher) to step down, who was replaced by the leader of the spade handle artisans. Finally, the last set of case studies investigates how cattle raising across the region has adjusted to the "amputation" of forest pasturelands via 
conservation constraints, resulting in lower cattle populations that spend more time in pens than in the forest. The chapter concludes that community-based resource management initiatives have, contrary to stated goals, largely resulted in a loss of authority by local communities over their life territories.

The following chapter (chap. 6) builds on this conclusion to develop a strong critique of environmental interventions in the area. It analyses the institutions, stakeholders, and power dynamics in the implementation of diverse environmental initiatives (from parks, to REDD + initiatives, to ecoregional plans, to community forest management instruments like GCF). It pays particular attention to the social and kinship dynamics of the COBA, the community institutions set up for GCF, and it shows how they encapsulate great asymmetries of power that can bypass or instrumentalize traditional power structures. It also shows how project "participation" is problematic in those forest villages where villagers spend much of the year away from the village, in field camps near their fields in the forest.

Rakoto Ramiarantsoa and Blanc-Pamard argue that these environmental interventions, while pushing the engagement of local people in forest conservation, continue to see nature and society as separate. The interventions conceptualize "forest" in ways that correspond poorly with local social organization. From the point of view of local actors, nature and society are inseparable. The forest is an indispensable resource for social and agricultural (re-)production. It is characterized not by its rarity (the point of view of conservationists) but by its place in the economic, social, and territorial system. On top of this, environmental initiatives end up reconfiguring relationships between villagers, which instead of leading to collective empowerment, lead to larger inequities.

Part 3 looks at how rural development and environmental protection are linked (or not) through two themes: land tenure and new ruralities. Chapter 7 centers on the tenure question. After reviewing the customary and official land tenure systems in the region, this chapter describes through examples how people have used many intermediate strategies (between customary and formal) to access land resources. Yet farmers have to bend to the norms and commands of an ecologized land tenure system where fields are now excluded from forest lands. The authors bemoan that recognition of traditional customary tenure was not the basis of biodiversity conservation policies.

The last empirical chapter (chap. 8) investigates a number of livelihood strategies that local people call on in an attempt to create what Rakoto Ramiarantsoa and Blanc-Pamard call "new ruralities", or the diverse, imperfect ways in which rural areas seek to dynamize themselves with linkages to the external world. Ecotourism is one strategy, but the offer so far is of poor quality and tightly linked to premium locations. As such, it is more a vector of inequalities than anything else. The train line is central to other strategies, as it is an essential axis for markets. Social networks relating to churches, especially the booming evangelical or charismatic Christian movements, occupy a significant space in people's lives. Trade networks in toaka gasy (locally brewed liquor) have redeveloped a new dynamism. Projects and NGOs have introduced lots of new activities, supported local economic organizations, and promoted water pumps, rural radios, and anti-erosion vetiver plantations. The authors conclude that undeniably, conservation politics in the forest corridor are a "plus" for the peasants. Numerous projects brought new tools, knowledges, and structures and opened space for new ideas, exchanges, and discussions. Yet these new realities are not that visible and perhaps not always that sustainable. The rural communities do not necessarily feel resourced, reinforced, or renewed. Not even their daily search for rice to eat has improved.

The final, concluding chapter, entitled "vers une biodiversité sans partage", argues that all the diverse conservation and development interventions in the rainforest and adjoining villages did not result in a "shared biodiversity", but instead put in place an "administered biodiversity". Local people and their knowledge were marginalized; local requests for a shared biodiversity were a low priority. More starkly, Rakoto Ramiarantsoa and Blanc-Pamard argue that the combined effect of interventions was environmental control, not sustainable development, and that as a result inequalities were reinforced. With the quasi-closure of the forest, poverty has deepened. Playing on the concept of how regional development has become écologisée, the authors suggest, in the final line, that perhaps instead an agricolisation of environmental policy might be the way to build a model for the future.

The book is generously illustrated with useful maps, pictures, and diagrams. Unfortunately, however, the system for numbering these is cumbersome - maps, photos, and figures are each numbered differently (so map 7 appears before Fig. 5); color illustrations are all placed in the middle of the book but still follow the categorical numbering system; and no table of figures exists to make sense of it all. The organization of the text is also at times a bit hard to follow, and there is regrettably no index.

Overall, however, this is yet another stellar contribution to the long-standing À travers champs series of research monographs published by IRD Éditions (the publishing house of the French government's Institut de recherche pour le développement, or Development Research Institute). This series, edited by Jean Boutrais, focuses on the "mutations" that are being experienced by today's rural societies and agrarian systems in tropical countries. This adventure by Rakoto Ramiarantsoa and Blanc-Pamard into the terrain of political ecology shows deftly how, in the Ranomafana corridor in Madagascar, the fight against poverty carried by conservation discourse is far, far removed from local realities. 


\section{References}

Bassett, T. J., Blanc-Pamard, C., and Boutrais, J.: Constructing locality: the terroir approach in West Africa, Africa, 77, 104-129, 2007.

Blanc-Pamard, C. and Rakoto Ramiarantsoa, H.: Lire la lune: cours du temps, rythmes climatiques et pratiques agricoles, XIIIe Congrés International des Sciences Anthropologiques et Ethnologiques, Mexico, 29 juillet-5 août 1993a.

Blanc-Pamard, C. and Rakoto Ramiarantsoa, H.: Les bas-fonds des hautes terres centrals de Madagascar: construction et gestion paysannes, in: Bas-fonds et Riziculture: Actes du Séminaire d'Antananarivo Madagascar 9-14 décembre 1991, edited by: Raunet, M., CIRAD, Montpellier, 31-47, 1993 b.

Blanc-Pamard, C. and Rakoto Ramiarantsoa, H.: Le Terroir et son Double: Tsarahonenana 1966-1992, Madagascar, À travers champs, IRD Editions, Paris, 254 pp., 2000.

Blanc-Pamard, C. and Rakoto Ramiarantsoa, H.: Une agriculture de montagne sur les Hautes Terres centrales de Madagascar: des innovations en réponse à l'urbanisation, in: Crise et Mutations des Agricultures de Montagne: Colloque International en Hommage au Professeur C. Mignon, edited by: Planel, S., Maire, R., Vanara, N., and Rosier, K., Presses Universitaires Blaise Pascal, Clermont-Ferrand, 351-367, 2003.
Blanc-Pamard, C. and Rakoto Ramiarantsoa, H.: Couleurs et savoirs des sols à Madagascar, in: L'érosion entre société, climat et paléoenvironnement: Table ronde en l'honneur du Pr. R. NeboitGuilhot, edited by: Allée, P. and Lespez, L., collection Nature et Sociétés no. 3, Clermont-Ferrand, 319-324, 2004.

Blanc-Pamard, C. and Rakoto Ramiarantsoa, H.: Normes environnementales, transferts de gestion et recompositions territoriales en pays betsileo (Madagascar), Natures Sciences Sociétés, 15, 253-268, 2007.

Gautier, D. and Hautdidier, B.: Connecting political ecology and French geography: on tropicality and radical thought, in: The International Handbook of Political Ecology, edited by: Bryant, R. L., Edward Elgar, Cheltenham, 57-69, 2015.

Rakoto Ramiarantsoa, H., Blanc-Pamard, C., and Pinton, F.: Géopolitique et environnement. Les leçons de l'expérience malgache, Marseille, éditions de l'IRD, 293 pp., 2012.

Robbins, P.: Political Ecology: A Critical Introduction, 2nd ed., Wiley, Oxford, 296 pp., ISBN-13: 978-0-470-65732-4, 2012. 